\title{
Relationships among dynamic capabilities dimensions in building competitive advantage: a conceptual model
}

\author{
Relações entre dimensões de capacidades dinâmicas na \\ construção da vantagem competitiva: proposta de um \\ modelo conceitual
}

\author{
Sandro Alves de Medeiros ${ }^{1}$ (D), Juliana Maria Magalhães Christino², Carlos Alberto Gonçalves ${ }^{2}$, \\ Márcio Augusto Gonçalves ${ }^{2}$ \\ ${ }^{1}$ Universidade Federal de Alagoas - UFAL, Campus Arapiraca, Unidade Penedo Penedo, Alagoas, Brasil. \\ E-mail: sandroamedeiros@gmail.com \\ ${ }^{2}$ Universidade Federal de Minas Gerais - UFMG, Centro de Pós-graduação e Pesquisas em Administração - \\ CEPEAD, Faculdade de Ciências Econômicas - FACE, Belo Horizonte, MG, Brasil. \\ E-mail: julianam.prof@gmail.com; carlos@face.ufmg.br; marcioag@face.ufmg.br
}

How to cite: Medeiros, S. A., Christino, J. M. M., Gonçalves, C. A., \& Gonçalves, M. A. (2020).

Relationships among dynamic capabilities dimensions in building competitive advantage: a conceptual model. Gestão \& Produção, 27(1), e3680. https://doi.org/10.1590/0104-530X3680-20

\begin{abstract}
In extremely dynamic sectors, whose structure is not so evident, both the approach based on the Structure-Conduct-Performance paradigm and the approach based on firm resources are limited to explain the sources of competitive advantages and the performance achieved by firms from their strategic choices. In this context, by focusing on the firm's adjustment to changes in highly dynamic environments, as well on the firm's facing challenges posed by volatile sectors, through integration, reconfiguration, renovation and allocation of its resources, skills and capabilities, the perspective of dynamic capabilities comes out as a promising approach to strategy studies not only to understand the sources of firm's sustainable advantages, but also to comprehend how such advantages are developed and implemented. The article consists of a theoretical essay that analyzes the concept of dynamic capabilities from the main definitions collected in the literature, by carrying out a conclusive synthesis and arguing about consulted theoretical contributions. The authors propose a theoretical model for the relationship among dynamic capabilities dimensions in order to explain how firms achieve and sustain competitive advantage, and also present the sense-making as a fundamental capacity for improving the effectiveness of other dynamic capabilities, serving as unifying element among them and favoring the alignment of the firm's strategic choices.
\end{abstract}

Keywords: Strategy; Competitive advantage; Dynamic capabilities; Organizational capabilities; Resource-based strategy.

Resumo: Em setores extremamente dinâmicos, cuja estrutura não se revela tão evidente, tanto a abordagem fundamentada no paradigma Estrutura-Conduta-Desempenho, quanto a abordagem baseada nos recursos se mostram limitadas para explicar as fontes das vantagens competitivas das firmas e o desempenho alcançado a partir de suas escolhas estratégicas. Nesse contexto, ao enfatizar o ajuste da firma às transformações de ambientes extremamente

Received Dec. 16, 2016 - Accepted July 23, 2017

Financial support: None.

This is an Open Access article distributed under the terms of the Creative Commons Attribution License, which permits unrestricted use, distribution, and reproduction in any medium, provided the original work is properly cited. 
dinâmicos e o enfrentamento dos desafios impostos por setores voláteis, por meio da integração, reconfiguração e renovação de seus recursos, competências e capacidades, a perspectiva das capacidades dinâmicas se apresenta como abordagem promissora não só para o entendimento das fontes de vantagens sustentáveis das firmas, mas de como tais vantagens são desenvolvidas e implementadas. $\mathrm{O}$ artigo consiste em um ensaio teórico que analisa o conceito de capacidades dinâmicas a partir das principais definições coletadas na literatura, fazendo uma síntese conclusiva e discutindo acerca das contribuições teóricas consultadas. Os autores propõem um modelo teórico das relações entre dimensões de capacidades dinâmicas para explicar a construção e a sustentação da vantagem competitiva, tendo a construção de sentido (sense-making) como capacidade fundamental, determinante para a melhoria da eficácia das demais capacidades dinâmicas, constituindo elemento unificador entre elas e possibilitando o direcionamento das decisões e escolhas estratégicas da firma.

Palavras-chave: Estratégia; Vantagem competitiva; Capacidades dinâmicas; Capacidades organizacionais; Estratégia baseada em recursos.

\section{Introduction}

The exponential speed of the social, political, technological and economic changes that have taken place since the second half of the 20th century and, vertiginously, from the years 1970 to 2000 , and still in progress, has become almost a common justification for practically any study of organizational phenomena. In the fields of marketing and strategy, the use of this argument is even more present, gaining status as a premise, that assumes that the firm needs to be attentive to events that occur beyond its boundaries and that, based on its interpretations of those events, it coordinates its resources, processes and decisions, in order to adapt to the consequences of those external events, thus reaching and sustaining competitive advantage.

The best perspective to the strategy studies that matches this orientation is the dynamic capabilities approach, which emerged in the mid-1990s as an alternative to existing approaches - the one that strongly emphasizes the operational environment of the organization, attributing to the industry structure the determinants of strategic choices for firms, and the one that brings the focus of analysis to the internal resources of the firm. With an eye looking at the environmental dynamic and its rapid transformations, and the other at the configuration and combination of resources, skills, processes, routines and capabilities of the firm, the dynamic capabilities approach seeks to overcome previous approaches, without necessarily denying them, but assuming a broader perspective of strategic analysis by including both the environmental dynamics, and the firm's resources, skills and capabilities.

In extremely dynamic industries, whose structure is not so evident, both, the approach based on the Structure-Conduct-Performance paradigm (Porter, 1992) and the resource-based view of the firm (Barney et al., 2001; Collis \& Montgomery, 1995; Peteraf, 1993; Wernerfelt, 1984) are limited in explaining the sources of firms' competitive advantages and the performance achieved from its strategic choices (Wang \& Ahmed, 2007; Eisenhardt \& Martin, 2000). In this context, by emphasizing the firm's adjustment to the transformations of extremely dynamic environments and facing the challenges imposed by volatile sectors, through the integration, reconfiguration and renewal of its resources, competences and capabilities, the perspective of dynamic capabilities comes out as a promising approach to strategy studies not only to understand the sources of firm's sustainable advantages, but also to comprehend how such advantages are developed and implemented (Li \& Liu, 2014; Teece et al., 1997). 
However, despite having achieved an important status in the field of strategy, the dynamic capabilities approach has received many criticisms that denounce the fragility of the concept itself and the consequent difficulty of its empirical testing, delaying the process of theorization and its acceptance as a referential model among strategists and chief executives officers (Li \& Liu, 2014; Meirelles \& Camargo, 2014; Barreto, 2010; Di Stefano et al., 2010; Danneels, 2008; Newbert, 2007; Zahra et al., 2006; Winter, 2003; Kraatz \& Zajac, 2001; Williamson, 1999).

The present paper consists of a theoretical essay that reviews the main definitions of dynamic capabilities, aiming to propose a theoretical model that explains the building of a firm's competitive advantage from the relations among the dimensions of dynamic capabilities suggested in the literature. The article is structured in four sections: in addition to this introduction, a second section presents a review of the dynamic capabilities concept and the main theoretical contributions; a third section discusses these contributions, synthesizes them and proposes a theoretical model of the firm's dynamic capabilities that explains how firms reach the competitive advantage; the concluding section summarizes the whole discussion and points out the gaps not covered by the study, showing directions and possibilities for future investigations to the refinement of the presented model and suggesting its empirical testing.

\section{Theoretical framework}

After a first attempt to introduce the concept of dynamic capabilities (Teece \& Pisano, 1994), without achieving great attention in the academic community, Teece et al. (1997) published in the Strategic Management Journal the article entitled, Dynamic capabilities and strategic management, marking the definitive introduction of the subject in the literature on strategic management. The publication caught the attention of renowned researchers in the area and provoked intense debate about the concept, which, in turn, triggered a vigorous and growing flow of research that extended beyond the boundaries of the original field, covering practically all sub-areas of the Management field (Barreto, 2010) and specific organizational processes - research and development, product and process development, technology transfer, intellectual property, production, human resource management, organizational learning, knowledge management, innovation, alliance formation, decision making, etc. (Zollo \& Winter 2002; Appleyard et al., 2001; Eisenhardt \& Martin, 2000; Teece et al., 1997).

Arising from the foundations of the Schumpeterian and Neoschumpeterian (evolutionary) approach to competition (Schumpeter, 1997; Nelson \& Winter, 1982), as well as from the perspective on strategy that emphasizes organizational resources [RBV] (Penrose, 2009; Rumelt, 2003; Peteraf, 1993; Barney, 1991; Wernerfelt, 1984), and also from the behavioral treatment of the theory of the firm (Selznick, 2003; Pierce et al., 2002; Simon, 1979), the dynamic capabilities approach highlights the exploration of the company's internal and external competences to face an environment of intense change, in a "[...] Schumpeterian world of innovation-based competition, price/performance rivalry, increasing returns, and the 'creative destruction' of existing competences" (Teece et al., 1997, p. 509).

Because it is a proposal of analysis and understanding about the organizational strategy still in an early stage of development, the dynamic capabilities approach has received several criticisms, which point out tautology and little robustness of its concepts, not properly operationalized, which provides weak support for empirical testing (Di Stefano et al., 2010; Danneels, 2008; Newbert, 2007; Zahra et al., 2006; 
Winter, 2003; Kraatz \& Zajac, 2001; Williamson, 1999). Furthermore, the different definitions provided by several streams of research have led to confusion about the meaning and usefulness of the concept, further hindering its theorizing process (Li \& Liu, 2014; Meirelles \& Camargo, 2014; Barreto, 2010).

Despite the difficulties that such a comprehensive concept entails in its process of maturation and acceptance by academicians in the field of strategic management, propositions of conceptual formulation and reformulation, besides empirical research have accumulated, which has led to some evolution towards theorization of the concept throughout almost 20 years. Originally, dynamic capabilities were defined as "[...] the firm's ability to integrate, build, and reconfigure internal and external competences to adress rapidly changing environments" (Teece et al., 1997, p. 516).

Implicit in this definition is the relationship of dynamic capabilities to organizational and managerial processes and practices, "the patterns of current practice and learning" or "the way things are done" (Teece et al., 1997, p. 518). For the authors, the origin of the firm's distinctive competences and dynamic capabilities is due to three categories of factors: (1) processes (organizational and managerial), (2) positions, and (3) paths (trajectories). Organizational processes are the essence of dynamic capabilities, while position refers to current specific allocations of technology, intellectual property, complementary assets, customer base, and external relations with suppliers and completors. In turn, trajectories are the strategic alternatives available to the company, as well as the presence or absence of increasing returns and the path dependencies.

Thus, for Teece et al. (1997), the essence of organizational skills and capabilities is embedded in organizational processes. However, the content of these processes and the opportunities they generate for the development of competitive advantage are shaped by the assets that a company possesses (internal and market) and the paths that it has followed. Therefore, according to Teece et al. (1997), organizational processes shaped by the positions of the company's assets and its trajectories can explain a firm's dynamic capabilities and competitive advantage reached by it.

In order to avoid tautology (by defining capability as "capacity") and assuming that dynamic capabilities are specific and identifiable sets of organizational routines and processes (such as product development, strategic decision making, alliances), Eisenhardt \& Martin (2000, p. 1107) define them as:

The firm's processes that use resources - specifically the processes to integrate, reconfigure, gain and release resources - to match and even create market change. Dynamic capabilities thus are the organizational and strategic routines by which firms achieve new resource configurations as markets emerge, collide, split, evolve, and die.

Eisenhardt \& Martin (2000) reinforce the original idea of dynamic capabilities as processes, but they extend the definition by including the creation of market change as well the response to exogenous changes. The authors also noted that dynamic capabilities can operate in environmental contexts where changes are not as fast and dynamic as those mentioned in previous definitions.

In order to explain the source of dynamic capabilities, by attributing their origin to organizational routines, and expanding their application to contexts of little environmental change, Zollo \& Winter (2002, p. 340) define dynamic capabilities as "[...] a learned and stable pattern of collective activity through which the organization systematically generates and modifies its operating routines in pursuit of improved effectiveness". With this definition, Zollo \& Winter (2002) put the origin of dynamic 
capabilities on organizational learning, and, in a implicit way, they make a distinction between dynamic capabilities and operational capabilities (Helfat et al., 2007).

By attributing to the dynamic capabilities the sources of entrepreneurial behavior and the causes of highest performance of companies that continuously create, define, discover and exploit business opportunities, Zahra et al. (2006, p. 918) define them as "[...] the abilities to reconfigure a firm's resources and routines in the manner envisioned and deemed appropriate by its principal decision-maker(s)". These researchers argue that, in fact, it is up to the entrepreneur or the entrepreneurial team or top management, to create and subsequently use the dynamic capabilities, from their perception about the opportunities to change, in a productive way, the configurations of the existing routines or resources and their willingness to make and implement such changes.

In contrast to definitions suggested by Eisenhardt \& Martin (2000) and Zollo \& Winter (2002), which directly relate dynamic capabilities to routines and organizational and operational processes, Helfat et al. (2007, p. 4) adopt a broader perspective, by defining dynamic capabilities as "[...] the capacity of an organization to purposefully create, extend, or modify its resource base".

The authors explain their divergence related to the previous argument that dynamic capabilities consist of organizational routines by the presence or absence of intentionality, which, according to them, would be absent in the organizational routines (Dosi et al., 2001), but present in the dynamic capabilities. In order to indicate the reflected intentionality in the dynamic capabilities, Helfat et al. (2007) use the adverb purposefully in their definition. However, Barreto (2010) questions this purposeful role attributed to dynamic capabilities due to the possibility of bringing even more controversy to the field of study, especially concerning difficulties of empirically testing the concept (ex-ante or ex-post).

Based on a deep review of the literature, by identifying convergences and conflicts among scholars, the theoretical gaps to be filled, and also considering the most recent conceptualization contributions, Barreto (2010) defines dynamic capability as "[...] the firm's potential to systematically solve problems, formed by its propensity to sense opportunities and threats, to make timely and market-oriented decisions, and to change its resource base" (Barreto, 2010, p. 271).

In choosing the adverb systematically in his definition for dynamic capabilities, Barreto (2010) emphasizes the importance of perceiving dynamic capability as something that is persistent and structured, such as the conceptualizations of Zollo \& Winter (2002). Furthermore, in defining capacity as a "potential", the researcher cleverly avoids the problem of tautology, which has been severely criticized by scholars who preceded him, besides highlighting the fact that, in order to achieve desired effects, dynamic capabilities must be exercised at all levels at any time (Winter, 2003).

The definition proposed by Barreto (2010) indicates that the dynamic capabilities are comprised of four distinct but related dimensions: (1) propensity to sense opportunities and threats; (2) timely decision-making; (3) market-driven decision-making; and (4) changing the resource base. This conception establishes a multidimensional (Edwards, 2001) and formative character for the dynamic capability concept. In this sense, the concept of dynamic capability is conceived as a multidimensional-aggregate construct (Law et al., 1998), that is, instead of being manifested through its dimensions (latent construct), the construct is actually formed by them. Thus, although the dimensions may be related to each other, there is no requirement for them to be highly correlated. In fact, the dimensions could even have no significant correlations among 
them (Law et al., 1998). With this contribution, the author seems to overcome some problems raised by earlier critics concerning the construct measurement.

Barreto (2010) further argues that the four dimensions that compose the dynamic capability construct were based on consistent previous research. In this sense, firstly, the propensity to change the resource base (creating, expanding, and reconfiguring the resource base) is aligned with the contributions of Helfat et al. (2007), Eisenhardt \& Martin (2000) and Teece et al. (1997). Secondly, the propensity to detect opportunities and threats is consistent with Teece's $(2007,1998)$ subsequent suggestions and with the argument that dynamic capability must incorporate a monitoring capability function that continuously assesses both the current available capacities and the changes in external environment (Schreyögg \& Kliesch-Eberl, 2007), besides the acknowledgement that managing opportunities and threats is a key element of dynamic capabilities (Gilbert, 2006). In addition, the propensity for timely decision making is supported by several studies, such as those of Moliterno \& Wiersema (2007), Pablo et al. (2007), Slater et al. (2006), Salvato (2003) and Rosenbloom (2000).

However, Barreto (2010) highlights two essential propensities related to decision making: (1) modification of the resource base, and (2) market orientation. The former concerns how quickly decisions are made to reconfigure and transform the resource base ahead of competition (Barney et al., 2001; Eisenhardt \& Martin, 2000; Teece et al., 1997), while the latter refers to how much the company systematically pays attention to ways that can deliver superior value to its customers (Priem, 2007).

In order to make the concept applicable to economies in transition (specifically the chinese economy), Li \& Liu (2014) undertake a modification in the definition of dynamic capabilities proposed by Barreto (2010), by disregarding the market-driven decision making dimension and emphasizing the implementation of strategic choices that guide a course of action, as suggested by Helfat et al. (2007).

This way, Li \& Liu $(2014,2794)$ define dynamic capabilities as '[...] the firms' potential to systematically solve problems, formed by its propensity to sense opportunities and threats, to make timely decisions, and to implement strategic decisions and changes efficiently to ensure the right direction". With this definition, the authors decompound the concept of dynamic capacities into three dimensions: (1) strategic capacity of sense-making, (2) timely decision-making, and (3) ability to implement change.

Li \& Liu (2014) explain that the strategic capacity of sense-making is the process of developing cognitive maps, perceiving and interpreting stimuli, or changing frames of reference to efficiently search for information from internal and external environments (Wohlgemuth \& Wenzel, 2016; Brown et al., 2015; Pandza \& Thorpe, 2009; Neill et al., 2007).

Timely decision-making capability refers to the process of formulating, evaluating, and choosing the strategic directions needed to adjust the firm to environmental change in a timely manner (Sharfman \& Dean, 1997).

The capacity to implement change consists of the ability to execute and coordinate strategic decisions and organizational change, by involving a variety of managerial and organizational processes, depending on the nature of the goal and the specific tasks required (Harreld et al., 2007; Helfat et al., 2007).

From the analysis of definitions of dynamic capabilities presented, some conclusions can be made. First, the problem of the lack of consensus among researchers concerning the term dynamic capability seems to lie in the difficulty of defining capability without committing a tautology, a recurrent criticism in the literature. 
Second, with respect to what dynamic capabilities are, scholars suggest that they involve processes (managerial and organizational), practices, routines and/or learned patterns of collective activities, skills and, finally, "potentials" or propensities (to solve problems related to external opportunities and threats, to make timely and market-oriented decisions, to modify the resource base, and to effectively implement strategic decisions and changes).

In relation to the sources of the dynamic capabilities, a common idea among different definitions is that the dynamic capabilities are embodied in the routines, processes and organizational practices, that form "patterns of current practice and learning", or "the way things are done" (Teece et al., 1997, p. 518), as well as the organization's own trajectory and choices made in this process. This way of conceiving dynamic capabilities points to the organizational learning processes as the seed of their development, the "[...] learned and stable pattern of collective activity [...]" (Zollo \& Winter, 2002, p. 340).

A consensus among scholars concerns the purpose of dynamic capabilities, that is, why they exist. In this sense, they serve to enhance organizational effectiveness, to build competitive advantage, and to make the organization resilient within the changing environment.

Another consensus among scholars is related to how dynamic capabilities act to fulfill their purpose, or how they "work". As Helfat et al. (2007) explain, this happens through both complex processes of decision-making and modification (integration, construction and reconfiguration) of the resource base itself, including the modification of other dynamic capabilities.

An inherent element to dynamic capabilities conceptualization is the external environment. There is almost unanimity among definitions concerning the idea that the organization is in an ongoing process of adaptation to the external changing environment. However, there are authors who argue that the organization itself can induce transformations in the environment, like Eisenhardt \& Martin (2000).

With regard to the degree of dynamism, the great majority of researchers associate the value of the use of dynamic capabilities to highly dynamic environments, with increasing value as changes in the dynamic environment demand greater use and specificity of the organizational capacities. Some authors, however, advocate the importance of dynamic capabilities in less hostile and variable environments (Zollo \& Winter, 2002; Eisenhardt \& Martin, 2000). In such cases, other forms of capabilities would be required.

The synthesis carried out by Barreto (2010) and the Li \& Liu's (2014) proposal to define categories for dynamic capabilities suggest and provide dimensions that compound the concept. In this sense, dynamic capability is a formative-multidimensional construct.

\section{Discussion}

From the analysis of the literature, some considerations about the dynamic capabilities dimensions will be presented, and then, based on these considerations, a theoretical model that explains the building of competitive advantage from the relationship among those dimensions will be proposed. The model tries to shed light on the "black box" approach of dynamic capabilities for organizational strategy, bringing a bit more concreteness to the concept, allowing for its better understanding and applicability. 
As seen in the previous section, the contributions of several scholars in the field suggest the existence of dimensions that compose the dynamic capabilities. The definitions proposed by Barreto (2010) and Li \& Liu (2014) suggest that there are 5 such dimensions: (1) identification of opportunities and threats: process of monitoring the external environment, by seeking signs of changes with potential to impact organizational present and future results; (2) market orientation: the ability to make strategic decisions always taking into account the demands of customers and continually seeking new ways to provide superior value to them; (3) modification of the resource base: process of assessing, formulating and deciding on the resource base, and appropriately defining the strategic guidelines needed to adjust to environmental changes, at the right time and in a timely manner, ahead of competitors; (4) implementation of change: ability to execute and coordinate strategic decisions and organizational change, involving a variety of managerial and organizational processes, according to the nature of the objective and the specific tasks required; (5) sense-making: process of developing cognitive maps, perceiving and interpreting stimuli, or changing frames of reference in order to efficiently analyze information from internal and external environments.

When analyzing the definitions of these dimensions it is possible to infer the existence of two directions, that is, two emphases or orientations to where the dynamic capability is directed: the external and internal environment. In this sense, the two dimensions - identification of opportunities and threats and market orientation - are focused on the external environment, that is, these dynamic capabilities have their resulting action oriented to what happens beyond the organizational boundaries. In turn, the other two dimensions - modification of the resource base and implementation of change - are oriented to the organization's internal environment. However, all dimensions together act to make the organization resilient within the changing environment and/or to develop and implement innovations and changes, which, in turn, lead the organization to reach and sustain competitive advantage. This systemic action of the dynamic capabilities takes place through another capacity, the sense-making capability.

The sense-making has an ambivalent orientation, that is, it is oriented both to the external and the internal environment. Moreover, sense-making is a fundamental capability for the effectiveness of all other dimensions of dynamic capabilities. Interpreting and figuring out meanings in the mass of information that arrives from the external environment is a necessary condition for opportunities and threats to be identified. In a similar way, to perceive and to understand changes in consumer preferences and tastes and try to "intuit" what could meet those new demands - which could lead to the development (often with the co-participation of customers) of products, services and innovations at high value for those clients - constitute an extremely relevant capacity for organizations that operate in highly dynamic and rapid cycle environments. Thus, the strategic capacity of sense-making is one of the fundamental organizational capabilities for the company's survival in quickly changing environments (Zahra \& George, 2002).

With respect to the internal environment, the sense-making capability helps companies to discover the advantages and disadvantages of their current resource base, contributing to the improvement of asset orchestration (Teece, 2014; Helfat et al., 2007). By systematically analyzing environmental transformations and assessing the current resource base, companies can better understand themselves and their competitors (Li \& Liu, 2014). In this way, the sense-making capabity permeates all 
choices and strategic decisions of the organization, and presents itself as a determining factor of the effectiveness of the other dynamic capabilities, besides being a unifying element among them, making possible the alignment of decisions and strategic choices.

Based on those arguments, an observation can be made regarding the list of dynamic capabilities presented in previous paragraphs: looking closer, it is noted that the ability to identify opportunities and threats seems to emphasize the outcome of the environmental monitoring process, which could be perceived as a broader category of dynamic capability, responsible for observing signs of changes in the environment. From this point, through sense-making capability, the potential external changes that could impact the organizational present and future results, could be perceived, that is, the effective identification of opportunities and threats would be achieved.

From the previous arguments, it is proposed to reformulate the original list of dynamic capabilities, by including the environmental monitoring capability, placing it as the antecedent of the identification of opportunities and threats, and having the sense-making capabiliy the guiding thread between them.

In the same way, another reformulation is suggested here, the addition of one more capability: resources assessment. Such capacity is nothing more than the decomposition of the capability of modifying resources. The ability to assess resources consists of the processes of surveying and disseminating the information about the position of the company's assets, as pointed out by Teece et al. (1997). In this sense, the resource assessment capability would be for resource modification capability, just as the environmental monitoring capability would be for the identification of opportunities and threats capability, as regards the temporal precedence.

This choice is justified by the explanatory power of placing sense-making as a fundamental dynamic capability for the effectiveness of all other ones, as already explained, by allowing the interpretation and dissemination of the network of meanings about the external and internal environments, thus enabling better decision making processes and the strategic choices alignment for the organization.

Having presented these arguments, the following conceptual model is proposed (Figure 1):

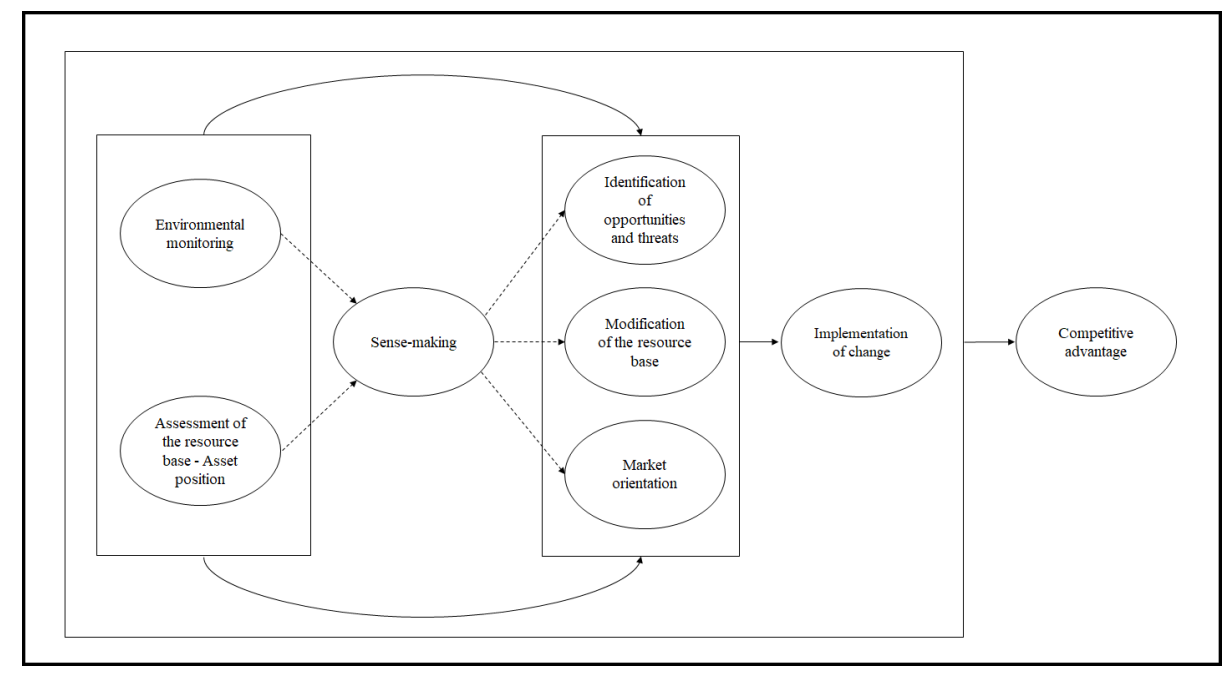

Figure 1. Relationships among Dimensions of Dynamic Capabilities in Building Competitive Advantage. Source: Authors' elaboration. 
The model departs from some assumptions: (1) first, the model assumes that dynamic capabilities are the organization's potential for problem solving (Li \& Liu, 2014; Barreto, 2010), and (2) they consist of processes (managerial and organizational), practices, routines and/or learned patterns of collective activities, and the potential to perform a task or to solve a problem (Li \& Liu, 2014; Barreto, 2010; Helfat et al., 2007; Winter, 2003; Zollo \& Winter, 2002; Zott, 2003; Eisenhardt \& Martin, 2000; Teece et al., 1997). In addition, (3) the model assumes that dynamic capabilities are formed by other dynamic capabilities, and presented as their dimensions, that is, dynamic capability is a multidimensional construct (Li \& Liu, 2014; Zahra \& George, 2002). Moreover, (4) dynamic capabilities achieve succesfully their purpose by means of complex decision-making processes and through modifying (integrating, constructing, and reconfiguring) their resource base (Li \& Liu, 2014; Barreto, 2010; Helfat et al., 2007; Zahra et al., 2006; Winter, 2003; Zollo \& Winter, 2002; Eisenhardt \& Martin, 2000; Teece et al., 1997). Finally, (5) the model assumes that dynamic capabilities have the potential to modify other dynamic capabilities (Helfat et al., 2007).

Thus, the proposed model is consistent with the theoretical formulations about the dynamic capacities collected in the literature and provides an explanation for the organizational system that generates the sustainable competitive advantage for the firm.

The full arrows indicate the path of the outcome produced by the immediately preceding dynamic capabilities, which trigger other dynamic capabilities and organizational processes. The dotted arrows show the most effective path for the effects of dynamic capabilities, through sense-making, which favors the collective understanding of the information produced by the previous dynamic capabilities, which, in turn, stimulates organizational learning and strategic alignment, by unifying the joint of dynamic capabilities.

This does not mean, however, that a dynamic capability necessarily has to pass through sense-making in order to trigger the next dynamic capabilities, although the effectiveness of all of them, taken together, can be appreciably improved when the most effective path is traveled. For example, efficient environmental monitoring can lead to the identification of opportunities and threats regardless of the interpretation resulting from sense-making. However, the accuracy of this identification process - hence its reliability and validity - will be potentially affected. Thus, the model suggests a moderating role for the sense-making capability, when it can modify the strenght of the influence of a precedent capability over a consequent one.

The larger rectangle, which contains all dynamic capabilities and the flows of relations among them, constitutes the whole set of dynamic capabilities of the firm, or the firm itself, taken as a set of resources and capacities. This abstraction is provided with the assumptions that dynamic capabilities are formed by other dynamic capabilities and that they can modify one another.

The ultimate result of this organizational "dynamics of the dynamic capabilities" is the building and sustaining of the firm's competitive advantage, indicated by the right-most ellipse. Even though it is possible to infer that dynamic capabilities can lead directly to superior organizational performance, there is no consensus among theorists and researchers about this point, although it is almost unanimous that dynamic capabilities support the firm's competitive advantage (Sigalas et al., 2013). 


\section{Final considerations}

The present theoretical essay has reviewed some of the main definitions of dynamic capabilities, by extracting from them an essential foundations synthesis. Based on the preceding discussion, the following conclusions could be summarized:

In order to avoid tautology in definitions, dynamic capabilities must be understood as the firm's potential to systematically solve problems arising from its propensity to detect opportunities and threats, make timely and market-oriented decisions, modify its resource base, and effectively implement strategic decisions and changes in order to ensure the correct direction (Li \& Liu, 2014; Barreto, 2010).

Dynamic capabilities comprise of processes (managerial and organizational), practices, routines and/or learned patterns of collective activities, skills and other capabilities and serve to improve organizational effectiveness, build and sustain competitive advantage and make the organization resilient in the external changing environment. In addition, dynamic capabilities modify the firm's resource base as well other dynamic capabilities. Finally, the definitions analysed lead to the conclusion that the dynamic capability concept can be understood as a formative-multidimensional construct.

The article discussed the dimensions of dynamic capabilities and proposed a theoretical model to explain the relationships among those dimensions in building competitive advantage. The model embodies sense-making capability as essential to the effectiveness of the other dynamic capabilities, assuming that it facilitates the collective understanding and dissemination of the information produced by these other capabilities, which, in turn, stimulates organizational learning and strategic alignment, by unifying the joint effect of all dynamic capabilities.

From the theoretical point of view, the article contributes to the understanding of the firm's competitive advantage formation based on the interrelationships of its dynamic capabilities, putting the sense-making capability as a connection link between the outcomes produced by dynamic capabilities directly linked to environmental monitoring and to resource base assessment, and the ones related to the identification of opportunities and threats, decision making and market orientation, still serving as a guiding thread to the network of meanings and interpretations among the dynamic capabilities.

Under the managerial perspective, the proposed model provides a way to make the complex and intricate terminology of dynamic capabilities a more understandable and applicable concept. The model also suggests an explanation for the building of the firm's competitive advantage, by opening the "black box model" of the firm's dynamic capabilities, which allows a better understanding of how this process takes place. With this, company strategists and chief executives can use the model as a reference for identifying and diagnosing which firm's dynamic capabilities must be developed and/or improved.

However, if on the one hand the proposed model has chosen being as parsimonious as possible, on the other hand, exactly because of this choice, it has sinned by omission, by not including possible "implicit" organizational processes or dimensions. Perhaps the most important of these processes or dimensions is the organizational learning, which underlies sense-making capability. Path dependence, that is, the strategic alternatives available to the company throughout its history, as well the presence or absence of increasing returns (Teece et al., 1997), also was not considered in the proposed model. The model also disregards the impact of dynamic capabilities on the firm's performance, opting for competitive advantage as the main 
result and purpose of the interactions among the dynamic capabilities dimensions. Further studies should seek to refine the proposed model, by incorporating such dimensions.

The empirical testing of the model is strongly recommended, both regarding the interrelationships of presented dimensions, and other related constructs, such as, for example, absorptive capacity (Zahra \& George, 2002), organizational learning (Zollo \& Winter, 2002), innovation capacity (Lin et al., 2016; Kindström et al., 2013; Hogan et al., 2011; Szeto, 2000), entrepreneurial orientation (Rodrigo-Alarcón et al., 2017; Martin \& Javalgi, 2016), as well as in different environmental contexts, which permits testing the hypothesis of the importance of dynamic capabilities in more unstable environments as opposed to less dynamic environments. (Mikalef \& Pateli, 2017; Martin \& Javalgi, 2016).

\section{References}

Appleyard, M. M., Hatch, N. W., \& Mowery, D. C. (2001). Managing the development and transfer of process technologies in the semiconductor industry. In G. Dosi, R. R. Nelson, \& S. G. Winter (Eds.), The nature and dynamics of organizational capabilities (pp. 183-207). Oxford: Oxford University Press. http://dx.doi.org/10.1093/0199248540.003.0008.

Barney, J. (1991). Firm resources and sustained competitive advantage. Journal of Management, 17(1), 99-120. http://dx.doi.org/10.1177/014920639101700108.

Barney, J. B., Wright, M., \& Ketchen, D. J., Jr. (2001). The resource-based view of the firm: ten years after 1991. Journal of Management, 27(6), 625-641. http://dx.doi.org/10.1177/014920630102700601.

Barreto, I. (2010). Dynamic capabilities: a review of past research and an agenda for the future. Journal of Management, 36(1), 256-280. http://dx.doi.org/10.1177/0149206309350776.

Brown, A. D., Colville, I., \& Pye, A. (2015). Making sense of sensemaking in organization studies. Organization Studies, 36(2), 265-277. http://dx.doi.org/10.1177/0170840614559259.

Collis, D. J., \& Montgomery, C. A. (1995). Competing on resources: strategy in the 1990s. Harvard Business Review, 73(4), 118-128.

Danneels, E. (2008). Organizational antecedentes of second-order competences. Strategic Management Journal, 29(5), 519-554. http://dx.doi.org/10.1002/smj.684.

Di Stefano, G., Peteraf, M., \& Verona, G. (2010). Dynamic capabilities deconstructed: a bibliographic investigation into the origins, development, and future directions of the research domain. Industrial and Corporate Change, 19(4), 1187-1204. http://dx.doi.org/10.1093/icc/dtq027.

Dosi, G., Nelson, R. R., \& Winter, S. G. (Ed.). (2001). The nature and dynamics of organizational capabilities. Oxford: Oxford University Press. http://dx.doi.org/10.1093/0199248540.001.0001.

Edwards, J. R. (2001). Multidimensional constructs in organizational behavior research: an integrative analytical framework. Organizational Research Methods, 4(2), 144-192. http://dx.doi.org/10.1177/109442810142004.

Eisenhardt, K. M., \& Martin, J. A. (2000). Dynamic capabilities: what are they? Strategic Management Journal, 21(10-11), 1105-1121. http://dx.doi.org/10.1002/10970266(200010/11)21:10/11<1105::AID-SMJ133>3.0.CO;2-E.

Gilbert, C. G. (2006). Change in the presence of residual fit: can competing frames coexist? Organization Science, 17(1), 150-167. http://dx.doi.org/10.1287/orsc.1050.0160. 
Harreld, J. B., O'Reilly, C. A., 3rd, \& Tushman, M. L. (2007). Dynamic capabilities at IBM: driving strategy into action. California Management Review, 49(4), 21-43. http://dx.doi.org/10.2307/41166404.

Helfat, C. E., Finkelstein, S., Mitchell, W., Peteraf, M., Singh, H., Teece, D., \& Winter, S. G. (2007). Dynamic capabilities: understanding strategic change in organizations. Malden: Blackwell Publishing.

Hogan, S. J., Soutar, G. N., McColl-Kennedy, J., \& Sweeney, J. C. (2011). Reconceptualizing professional service firm innovation capability: scale development. Industrial Marketing Management, 40(8), 1264-1273. http://dx.doi.org/10.1016/j.indmarman.2011.10.002.

Kindström, D., Kowalkowski, C., \& Sandberg, E. (2013). Enabling service innovation: a dynamic capabilities approach. Journal of Business Research, 66(8), 1063-1073. http://dx.doi.org/10.1016/j.jbusres.2012.03.003.

Kraatz, M. S., \& Zajac, E. J. (2001). How organizational resources affect strategic change and performance in turbulent environments: theory and evidence. Organization Science, 12(5), 632-657. http://dx.doi.org/10.1287/orsc.12.5.632.10088.

Law, S. L., Wong, C.-S., \& Mobley, W. H. (1998). Toward a taxonomy of multidimensional constructs. Academy of Management Review, 23(4), 741-755. http://dx.doi.org/10.5465/amr.1998.1255636.

Li, D.-Y., \& Liu, J. (2014). Dynamic capabilities, environmental dynamism, and competitive advantage: evidence from China. Journal of Business Research, 67(1), 2793-2799. http://dx.doi.org/10.1016/j.jbusres.2012.08.007.

Lin, H.-F., Su, J.-Q., \& Higgins, A. (2016). How dynamic capabilities affect adoption of management innovations. Journal of Business Research, 69(2), 862-876. http://dx.doi.org/10.1016/j.jbusres.2015.07.004.

Martin, S. L., \& Javalgi, R. G. (2016). Entrepreneurial orientaion, marketing capabilities and performance: the moderating role of competitive intensity on Latin American international new ventures. Journal of Business Research, 69(6), 2040-2051. http://dx.doi.org/10.1016/j.jbusres.2015.10.149.

Meirelles, D. S., \& Camargo, A. A. B. (2014). Capacidades dinâmicas: o que são e como identificá-las. RAC, 18, ed. esp., 41-64.

Mikalef, P., \& Pateli, A. (2017). Information technology-enabled dynamic capabilities and their indirect effect on competitive performance: findings from PLS-SEM and fSQCA. Journal of Business Research, 70, 1-16. http://dx.doi.org/10.1016/j.jbusres.2016.09.004.

Moliterno, T. F., \& Wiersema, M. F. (2007). Firm performance, rent appropriation, and the strategic resource divestment capability. Strategic Management Journal, 28(11), 10651087. http://dx.doi.org/10.1002/smj.630.

Neill, S., McKee, D., \& Rose, G. M. (2007). Developing the organization's sense-making capability: precursor to an adaptive strategic marketing response. Industrial Marketing Management, 36(6), 731-744. http://dx.doi.org/10.1016/j.indmarman.2006.05.008.

Nelson, R. R., \& Winter, S. G. (1982). An evolutionary theory of economic change. Cambridge: Belknap Press of Harvard University Press.

Newbert, S. (2007). Empirical research on the Resource-Based View of the firm: an assessment and suggestions for future research. Strategic Management Journal, 28(2), 121-146. http://dx.doi.org/10.1002/smj.573.

Pablo, A. L., Reay, T., Dewald, J. R., \& Casebeer, A. L. (2007). Identifying, enabling and managing dynamic capabilities in the public sector. Journal of Management Studies, 44(5), 687-708. http://dx.doi.org/10.1111/j.1467-6486.2006.00675.x.

Pandza, K., \& Thorpe, R. (2009). Creative search and strategic sense-making: missing dimensions in the concept of dynamic capabilities. British Journal of Management, 20, 118131. http://dx.doi.org/10.1111/j.1467-8551.2008.00616.x. 
Penrose, E. (2009). The theory of growth of the firm (4th ed.). Great Britain: Oxford Univesity Press.

Peteraf, M. A. (1993). The cornerstones of competitive advantage: a resource-based view. Strategic Management Journal, 14(3), 179-191. http://dx.doi.org/10.1002/smj.4250140303.

Pierce, J. L., Boerner, C., \& Teece, D. (2002). Dynamic capabilities, competence, and the behavioral theory of the firm. In M. Augier, J. G. March (Eds.), The economics of change, choice and structure: essays in the memory of Richard M. Cyert (pp. 81-95). Cheltenham: Edward Elgar Publishing.

Porter, M. E. (1992). Vantagem competitiva; criando e sustentando um desempenho superior (5. ed.). Rio de Janeiro: Campus.

Priem, R. L. (2007). A consumer perspective on value creation. Academy of Management Review, 32(1), 219-235. http://dx.doi.org/10.5465/amr.2007.23464055.

Rodrigo-Alarcón, J., García-Villaverde, P. M., \& Ruiz-Ortega, M. J. (2017). From social capital to entrepreneurial orientation: the mediating role of dynamic capabilities. European Management Journal, 36(2), 1-15. https://doi.org/10.1016/j.emj.2017.02.006.

Rosenbloom, R. S. (2000). Leadership, capabilities, and technological change: the transformation of NCR in the electronic era. Strategic Management Journal, 21(10-11), 1083-1103. http://dx.doi.org/10.1002/1097-0266(200010/11)21:10/11<1083::AIDSMJ127>3.0.CO;2-4.

Rumelt, R. P. (2003). Towards a strategic theory of the firm. In N. J. Foss (Ed.), Resources, firms, and strategies: a reader in the resource-based perspective (pp. 131-145). Great Britain: Oxford University Press.

Salvato, C. (2003). The role of micro-strategies in the engineering of firm evolution. Journal of Management Studies, 40(1), 83-108. http://dx.doi.org/10.1111/1467-6486.t01-2-00005.

Schreyögg, G., \& Kliesch-Eberl, M. (2007). How dynamic can organizational capabilities be? Towards a dual-process model of capability dynamization. Strategic Management Journal, 28(9), 913-933. http://dx.doi.org/10.1002/smj.613.

Schumpeter, J. A. (1997). Teoria do desenvolvimento econômico; Uma investigação sobre lucros, capital, crédito, juro e o ciclo econômico. São Paulo: Nova Cultural.

Selznick, P. (2003). Leadership in administration: a sociological interpretation. In: N. J. Foss (Ed.), Resources, Firms, and Strategies: A Reader in the resource-based perspective (pp. 21-26). Great Britain, Oxford University Press.

Sharfman, M. P., \& Dean, J. W., Jr. (1997). Flexibility in strategic decision making: informational and ideological perspectives. Journal of Management Studies, 34(2), 191-217. http://dx.doi.org/10.1111/1467-6486.00048.

Sigalas, C., Pekka Economou, V., \& B. Georgopoulos, N. (2013). Developing a measure of competitive advantage. Journal of Strategy and Management, 6(4), 320-342. http://dx.doi.org/10.1108/JSMA-03-2013-0015.

Simon, H. A. (1979). Comportamento administrativo: estudo dos processos decisórios nas organizações administrativas. Rio de Janeiro: FGV.

Slater, S. F., Olson, E. M., \& Hult, G. T. M. (2006). The moderating influence of strategic orientation on the strategy formation capability-performance relationship. Strategic Management Journal, 27(12), 1221-1231. http://dx.doi.org/10.1002/smj.569.

Szeto, E. (2000). Innovation capacity: working towards a mechanism for improving innovation within an inter-organizational network. The TQM Magazine, 12(2), 149-158. http://dx.doi.org/10.1108/09544780010318415.

Teece, D. J. (1998). Capturing value from knowledge assets: the new economy, markets for know-how and intangible assets. California Management Review, 40(3), 55-79. http://dx.doi.org/10.2307/41165943. 
Teece, D. J. (2007). Explicating dynamic capabilities: the nature and microfoundations of (sustainable) enterprise performance. Strategic Management Journal, 28(13), 1319-1350. http://dx.doi.org/10.1002/smj.640.

Teece, D. J. (2014). A dynamic capabilities-based entrepreneurial theory of the multinational enterprise. Journal of International Business Studies, 45(1), 8-37. http://dx.doi.org/10.1057/jibs.2013.54.

Teece, D. J., \& Pisano, G. (1994). The dynamic capabilities of firms: an introduction. Industrial and Corporate Change, 3(3), 537-556. http://dx.doi.org/10.1093/icc/3.3.537-a.

Teece, D. J., Pisano, G., \& Shuen, A. (1997). Dynamic capabilities and strategic management. Strategic Management Journal, 18(7), 509-533. http://dx.doi.org/10.1002/(SICl)10970266(199708)18:7<509::AID-SMJ882>3.0.CO;2-Z.

Wang, C. L., \& Ahmed, P. K. (2007). Dynamic capabilities: a review and research agenda. International Journal of Management Reviews, 9(1), 31-51. http://dx.doi.org/10.1111/j.1468-2370.2007.00201.x.

Wernerfelt, B. A. (1984). Resource-based view of the firm. Strategic Management Journal, 5(2), 171-180. http://dx.doi.org/10.1002/smj.4250050207.

Williamson, O. (1999). Strategy research: governance and competence perspectives. Strategic Management Journal, 20(12), 1087-1108. http://dx.doi.org/10.1002/(SICI)10970266(199912)20:12<1087::AID-SMJ71>3.0.CO;2-Z.

Winter, S. (2003). Understanding dynamic capabilities. Strategic Management Journal, 24(10), 991-995. http://dx.doi.org/10.1002/smj.318.

Wohlgemuth, V., \& Wenzel, M. (2016). Dynamic capabilities and routinization. Journal of Business Research, 69(5), 1944-1948. http://dx.doi.org/10.1016/j.jbusres.2015.10.085.

Zahra, S. A., \& George, G. (2002). Absorptive capacity: a review, reconceptualization and extension. Academy of Management Review, 27(2), 185-203. http://dx.doi.org/10.5465/amr.2002.6587995.

Zahra, S. A., Sapienza, H. J., \& Davidsson, P. (2006). Entrepreneurship and dynamic capabilities: a review, model and research agenda. Journal of Management Studies, 43(4), 917-955. http://dx.doi.org/10.1111/j.1467-6486.2006.00616.x.

Zollo, M., \& Winter, S. G. (2002). Deliberate learning and the evolution of dynamic capabilities. Organization Science, 13(3), 339-351. http://dx.doi.org/10.1287/orsc.13.3.339.2780.

Zott, C. (2003). Dynamic capabilities and the emergence of intraindustry differential firm performance: insights from a simulation study. Strategic Management Journal, 24(2), 97125. http://dx.doi.org/10.1002/smj.288. 